\title{
The Effect of Some Economic Variables on Economic Growth in Indonesia Period 2010- 2017
}

\author{
Nur Azm Karim, Chyntia Ika Ratnapuri
}

\begin{abstract}
Exchange rate fluctuations are caused by interactions between economic factors and non-economic factors. The purpose of this study is to see the effect of the fluctuations in the rupiah exchange rate on economic growth along with several macro variables in Indonesia. The analytical method used in this study is multiple regression methods, namely testing the hypothesis about the effect of rupiah exchange rate fluctuations (KURS), inflation (INF), Foreign Direct Investment (FDI), Indonesian bank certificate interest rate (SBI), and Money Supply (JUB ) to the Indonesian economy (GRDP). The data used in this study are secondary data taken from Bank Indonesia, the Central Bureau of Statistics, and the World Bank. The research method used is multiple linear regrelsi method using eviews application. The results of this study indicate the exchange rate, inflation and the money supply have a negative direction with economic growth while foreign investment (FDI) and interest rates on Bank Indonesia Certificates (SBI) have a positive and significant direction towards economic growth in Indonesia.
\end{abstract}

Keywords: Exchange Rate, Inflation, FDI Indonesian bank certificate interest rate, Money supply, GRDP

\section{INTRODUCTION}

In its capacity as a central bank, Bank Indonesia has a single goal, which is the goal to achieve and maintain the stability of the rupiah exchange rate. The stability of the rupiah exchange rate contains two aspects, namely the stability of the currency value of goods and services, and the stability of the currencies of other countries. The first aspect is reflected in the development of the inflation rate, while the second aspect is reflected in the development of the rupiah exchange rate against other currencies (exchange rates). Regarding these objectives, it is explained that Bank Indonesia knows the limits of its responsibilities and clarifies the goals it wants to achieve [1].

The rupiah exchange rate was influenced both by monetary policy and fiscal policy. To prevent the fluctuation of the rupiah exchange rate from stabilizing inflation, interest rates, exports, imports, the money supply and foreign debt to prevent fluctuations. The rupiah exchange rate in 2016 generally moved in a stronger direction with declining volatility.

Revised Manuscript Received on October 22, 2019.

* Correspondence Author

Nur Azmi Karim*, Binus University, Indonesia. Email: nur.karim@binus.ac.id

Chyntia Ika Ratnapuri*, Binus University, Indonesia Email: chyntia.ratnapuri@binus.ac.id
The strengthening of the rupiah exchange rate was fundamentally influenced by the improvement in Indonesia's balance of payments performance, including due to increased foreign capital inflows in line with positive investor perceptions of the economic outlook. The strengthening of the rupiah is also inseparable from the positive influence of the policies adopted by Bank Indonesia regarding exchange rates.

Activities for the application of the precautionary principle for corporations that have foreign debt, and the obligation to use the Rupiah. The strengthening of the rupiah in 2016 was also followed by improvements in the composition of capital traffic in the foreign exchange market and the strengthening of the structure of the domestic foreign exchange market fluctuations in the Rupiah exchange rate influenced by both monetary policy and fiscal policy. In line with the enactment of Law Number 23 of 1999 concerning the Central Bank concerning the effectiveness of monetary policy on the floating exchange rate system the monetary authority has changed the operating system of monetary policy from an operating system based on the intermediate targeting applied during the implementation of a controlled floating exchange rate system into an inflation based operating system targeting.

Based on the description of the research the formulation of the problem is 1). How is the influence of inflation, FDI, SBI, the amount of money circulating, and the fluctuation of the Rupiah exchange rate against economic growth in Indonesia throughout 2010 - 2017; 2). How much influence is inflation, FDI, SBI, Money Supply, and the fluctuation of the Rupiah exchange rate against economic growth in Indonesia throughout 2010 - 2017. The purpose of this study is (i) to compile a model of economic growth that can explain empirically Indonesia's economic growth, (ii) obtain empirical evidence regarding the relationship between economic variables and Indonesia's economic growth and the magnitude of their influence on economic growth rates, (iii) obtain an overview of the decomposition of the effects of economic variables on economic growth. The targeted results are all variables that have significant and significant impact on economic growth in Indonesia and can be implemented in the implementation of increasing economic growth in Indonesia. This research is also expected to be a reference for further research using other economic variables and with the use of different analytical tools. 


\section{LITERATU RE RIVIEW AND DATA ANALYSIS}

\section{A. Literature Riview}

Economic growth is the main source in efforts to improve people's living standards. [2] Defines economic growth as an increase in the ability of an economy to produce goods and services. Economic growth shows more on quantitative changes (quantitative change) and is usually measured using gross domestic product (GDP) or per capita income. Main purpose of calculating economic growth is to see whether the economic conditions are getting better or vice versa [3]. The size of the bad can be seen from the production structure (sectoral) and the area of origin of production (regional). The high national economic growth reflects the better management of various aspects of regional macroeconomic magnitudes such as money supply, BI interest rates, inflation, FDI, and exchange rate fluctuations which will ultimately lead to increased regional production. The concept of economic growth in a period is:

$$
\mathrm{Gt}=\frac{G R D P_{t}-G R D P_{t-1}}{G R D P_{t-1}} \times 100 \%
$$

Where:

$\mathrm{Gt}=$ economic period $\mathrm{t}$ (quarterly or annual)

GRDPt $=$ Real Gross Domestic Product period $\mathrm{t}$ (based on constant prices)

GRDPt-1 = GRDP one previous period products will certainly lead to reduced cash circulation.

\section{B. Relationship between Exchange Rates (Exchange Rate) and Economic Growth}

The exchange rate of a country's currency, known as the exchange rate, is distinguished by the nominal exchange rate and the real exchange rate. The nominal exchange rate is the relative price of two countries' currencies [4]. An exchange rate is an agreement known as a currency exchange rate for payments now or in the future, between two currencies of each country or region. Several empirical studies conducted to see the effect of the exchange rate on economic growth, among others 183 developing and developed countries show that in the increasingly inflexible developing countries the exchange rate of a country, the lower the growth rate its economy; while in developed countries there is no significant difference in the use of the fixed and floating exchange rate system [5]. Meanwhile the study conducted shows that the fixed and intermediate exchange rate system produces a better growth rate than the floating exchange rate system [6]. Several other studies also produce diverse conclusions. The results of empirical studies that are not in line make these problems interesting to study, especially to find out specifically the case of Indonesia.

\section{The Effect of Inflation on Economic Growth}

Inflation is the tendency for an increase in the price of products as a whole which comes from the disruption of the balance between money flows and goods flows [7]. High inflation is usually associated with overheated economic conditions, which means that the demand for a product exceeds the capacity of its product offerings, so prices tend to increase[8]. A market economy uses prices as a measure of economic values. The increase in inflation in a period caused the public to worry about their decreasing income. This is what ultimately leads to economic inefficiency. Inflation is measured by the level of price change in general, with the following equation:

Rate of Inflation $=\frac{{\text { Price } \text { Level }_{t}-\text { Price }_{\text {Level }}-1}_{\text {Price } \text { Level }_{t}}}{\text { P }}$ 100\%

In principle, not all inflation has a negative impact on the economy. Especially if there is mild inflation below ten percent. Mild inflation can actually encourage economic growth. This is because inflation is able to encourage entrepreneurs, to further increase production. Entrepreneurs are eager to expand their production, because with the price increases that occur the entrepreneurs get more profits. In addition, increasing production has another positive impact, namely the availability of new jobs. Inflation will have a negative impact if the value exceeds ten percent.

From the results of research about relationship betwen inflation and economic growth shows the inflation rate does not have a significant effect on economic growth in Indonesia [9]. This is evidenced by the t test which shows a significance value of $0.1935>\alpha(0.05)$. This finding is also in accordance with the previous study which concluded that inflation did not significantly influence the economic growth of Bali Province [10].

\section{The Effect of FDI on Economic Growth}

Foreign Direct Investment (FDI) is a long-term investment for developing countries. The arrival of foreign direct investment (FDI) can help economic development, in terms of capital development and creating jobs. The presence of foreign direct investment (FDI) will create new sources. According to the sources of financing originating from foreign direct investment are the most potential foreign financing compared to other financing sources[11]. Investment activities allow a society to continuously improve economic activities and employment opportunities, increase national income and increase the level of prosperity of the community. In the macro economy the increase in investment will increase aggregate demand and national income. The increase in aggregate demand will bring an increase in the production capacity of an economy which will then be followed by increases in the need for labor for the production process, which means an increase in employment opportunities [12].

Research related to the effect of FDI on economic growth was carried out where the result was that foreign investment directly had a positive impact on economic growth, especially in the financial sector [13]. Research on foreign investment has a positive impact on the economy of the host country because through foreign investment can increase the availability of funds for the host country (recipient country) [14]. Athukorala also conducted research using the cointegration econometric model and serial data from 1959 to 2012 to analyze the relationship between FDI and GDP in Sri Lanka. The results show that FDI has a positive effect on GDP and a causal relationship between FDI and GDP in Sri Lanka.

Lipsey also found that the flow of foreign direct investment (FDI) had an impact positive for the host. But the results of the research conducted did not find significant relationship between FDI and economic 
growth, especially for medium-sized countries developing. Research on the impact of FDI and human capital on economic growth in China by using data panels of cities in China from 1991 to 2010 [15]. They tested the determinants of economic growth with a focus on the role of FDI and human capital with the Solow model human capital-augmented approach.

\section{E. The Effects of SBI Interest Rates on Economic Growth}

Bank Indonesia Certificates (SBI) are securities issued by Bank Indonesia and are one component used by the government to control the money supply. SBI interest rates are a reference for the rate of return obtained by investors when investing in risk-free investments. Changes to the capital market to determine the exchange rate balance in the open economy have been widely studied by several experts, the interest rate is the cost or price of a loan or credit. The interest rate of Bank Indonesia Certificates (SBI) is the interest rate of the auction results of Bank Indonesia Certificates (SBI) and is one of the methods used by the monetary authority to control the money supply which in turn will maintain price level stability.

Theory of Bank Indonesia Certificate Interest (SBI) from interest is payments made for the use of money [16]. The interest rate is the amount of interest paid per unit of time called a percentage of the amount lent [17]. The interest rate states the level of payment for loans or other investments, above the repayment agreement, which is expressed as an annual percentage. The interest rate of Bank Indonesia Certificates is the interest rate resulting from the auction of Bank Indonesia Certificates, hereinafter referred to as SBIs, are securities denominated in Rupiah issued by Bank Indonesia in recognition of short-term debt.

\section{F. The Effect of the Amount of Money Circulating Against Economic Growth}

Currency stability is an important issue to encourage economic activity and create economic growth. The policy of stabilizing the exchange rate is related to the foreign exchange system applied to an economy. The selection of an exchange rate system in broad outline can be viewed from three aspects, namely the characteristics of the economic structure, the source of shock and the credibility of the policy maker. Research on currency value fluctuations using the $\mathrm{ARCH}$ (autoregressive conditional heteroscedasticity) method [18], this research is also used to predict currency fluctuations in the future. In his research, it was formulated that the relative increase in the money supply or a decrease in the level of relative income would cause exchange rate depreciation as well as if there was an increase in the domestic interest rate. Research on currency fluctuations was also carried out, namely to find out the factors that encourage volatility in currency exchange and capital control both on the black market and the official market [19]. In his research note that the ability to predict exchange rate volatility from the GARCH method provides more precise accuracy of market information compared to two other traditional measurement methods.

Based on the results of previous empirical research which became the basis for conducting research, the research flow of thinking is to formulate research as a brief description of the research process and flow to be carried out as follows:

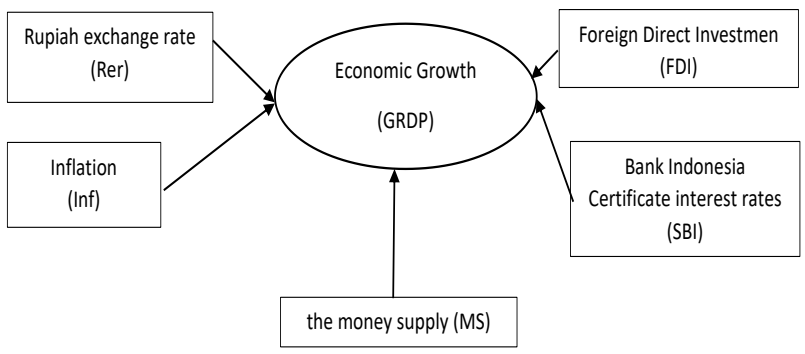

Figure 2.1 Process and Research Thinking Flow

From the flow of thought a mathematical equation can be formulated to be able to see each influence of economic variables on economic growth in Indonesia throughout 2010 2017 , is :

GRDP $=\mathrm{f}($ Rer, Inf, FDI, SBI, MS $)$

The specifications of structural equation models are explained as follows:

GRDP $=\lambda+\beta 1$ Rer $+\beta 2$ Inf $+\beta 3$ FDI $+\beta 4$ SBI $+\beta 5 \mathrm{MS}+\varepsilon$

When :

GRDP = Economic growth measured by GRDP (\%)

Rer $=$ Rupiah exchange rate against USD

Inf $=$ inflation rate in Indonesia (\%)

FDI $=$ Foreign Direct Investment $/$ foreign investment $(\%)$

$\mathrm{SBI}=$ Bank Indonesia Certificate interest rate $(\%)$

MS = Money supply in Indonesia (\%)

In general, this study intends to analyze and see the influence of Rer, Inflation, FDI, SBI, and MS on economic growth in Indonesia during the period 2010-2017.

\section{DATA ANALYSIS}

The type of data in this study is secondary data which is time series data. The data collected is sourced from the Central Statistics Agency (BPS), Bank Indonesia (BI), and other data sources in the period 2010-2017. The data collected includes inflation rate data, Rupiah exchange rate data, Foreign Direct Investment (FDI) data, data on interest rates for Bank Indonesia Certificates, data on money supply, and data on Indonesia's economic growth.

The analytical method used is the multiple linear regression method Regression is a linear regression model involving more than one independent variable (predictor) which is a statistical tool used to determine the effect of one or several variables on one variable. Regression analysis will be analyzed in a regression equation where the regression equation is a measuring tool that can also be used to measure the presence or absence of correlation between variables. Regression analysis studies the relationships obtained expressed in mathematical equations which state the functional relationships between variables.

Some testing methods that will be carried out in this analysis are some tests that are often carried out in a multiple regression analysis, namely:

1. Unit Roots Test, a data or variable is called stationary if the mean and variance is 
constant during the observation period. If the data is stationary, it can be assumed that the data used can be translated well in an economic model because the data will not be too varied. If the data used is too varied, it can cause spurious regression. To find out whether the stationary data or not is done stationary test with unit root tests (unit roots test) which will be compared with the critical value table values.

2. Model Fitness Test (Goodness of Fit Test), is a test to see whether the formulated model can explain variations in changes in endogenous variables carried out by a model matching test (goodness of fit test). This test looks at the coefficient of determination (R2), if the value of R2 is high, it means the formulated model can explain the variation in the change in endogenous variables and vice versa.

3. Partial Test Parameter (T-Test), is to find out the partial effect of each independent variable on endogenous variables in the reduced form equation. If the $t$-value is greater than the $\mathrm{t}$-critical value, then Ho is rejected, which means that the independent variable significantly influences the endogenous variable, which means that the sign and the magnitude of the parameters have significance in a model.

4. Overall Significance Test, the interpretation of the calculation results is as follows if the $F$ value is greater than the $F$ table at a certain degree of error $(\alpha)$ with degrees of freedom $\mathrm{k}-1$ and $\mathrm{N}-1$, then Ho is rejected. This can be interpreted that the independent variables together significantly influence endogenous variables and vice versa.

5. Classical Assumption Test, to obtain valid and accurate estimation results, the estimation parameters must pass the classic assumption test, namely the autocorrelation test, multicollinearity test and heteroscedasticity.

\section{EMPIRICAL MODEL AND ESTIMATION}

Indonesia's economic growth is influenced by several factors including the amount of money in circulation, inflation, SBI interest rates, the exchange rate of the Dollar against the Rupiah, FDI. In this study using the method of multiple linear regression to see the effect of these macro variables on economic growth in Indonesia during 2010 2017. The regression equation that is performed can be seen in Table 1, as follows:

Table 1. Regression Equations

\begin{tabular}{crrrr}
\hline \hline Variable & Coefficient & Std. Error & t-Statistic & Prob. \\
\hline \hline C & 67.82345 & 14.32107 & 4.735921 & 0.0418 \\
LOG(FDI) & 2.038225 & 0.407278 & 5.004502 & 0.0377 \\
INF & 0.029000 & 0.017225 & 1.683627 & 0.2343 \\
LOG(MS) & -4.784146 & 1.210604 & -3.951867 & 0.0585 \\
LOG(RER) & 2.330346 & 1.486988 & 1.567159 & 0.2576 \\
SBI & -0.369162 & 0.089009 & -4.147469 & 0.0535 \\
\hline \hline & & & & \\
R-squared & 0.977702 & Mean dependent var & 5.591250 \\
Adjusted R-squared & 0.921958 & S.D. dependent var & 0.497320 \\
S.E. of regression & 0.138931 & Akaike info criterion & -0.995972 \\
Sum squared resid & 0.038604 & Schwarz criterion & -0.936391 \\
Log likelihood & 9.983890 & Hannan-Quinn criter. & -1.397823 \\
F-statistic & 17.53910 & Durbin-Watson stat & 2.995972 \\
Prob(F-statistic) & 0.054815 & & & \\
\hline \hline
\end{tabular}

Sources : Data Processed ; *** significance at $\alpha=1 \%$;* significance at $\alpha=$ $5 \%$; significance at $\alpha=10 \%$

Interpretation of Regression Equations

GDP $=67,82+2,04 \mathrm{fdi}+0,03 \mathrm{inf}-4,78 \mathrm{~ms}+2,33 \mathrm{rer}-0,37 \mathrm{sbi}+\varepsilon(6)$

The constant value $(\beta 0)$ can be interpreted that if all the independent variables are zero, then economic growth will increase by $67.82 \%$. The FDI coefficient of 2.04 explains that if foreign investors add investment in Indonesia by $1 \%$ will increase economic growth by $2.09 \%$ assuming the other variables are ceteris paribus. The money supply (ms) shows a negative effect where if the money supply increases by $1 \%$ it will reduce economic growth by $4.78 \%$. The amount of money circulating in the community if used wisely to support the real sector will increase investment. The use of the money supply if spent to purchase venture capital will ultimately support industrial sectors (the real sector) which in turn will create balanced economic growth.

SBI interest rates have a coefficient of -0.37 , which means that SBI interest rates have a negative influence on economic growth. This means that if the SBI interest rate increases by $1 \%$, economic growth will decrease by $0.37 \%$. Low interest rates will ultimately affect the growth of economists. Inflation variable and Rupiah exchange rate against US Dollar (rer) do not affect economic growth.

Based on the estimation results in table 1, the F-Statistics value of 17.54 can be interpreted which means that all independent variables simultaneously influence economic growth. R2 value of 0.98 means that the variation of changes in all independent variables affect economic growth of $0.98 \%$ while the remaining $0.02 \%$ is influenced by variables not included in this research model.

Research on the impact of FDI and human capital on economic growth in China using a data panel of cities in China from 1991 to 2010 [15]. They tested the determinants of economic growth with a focus on the role of FDI and human capital with the human capital-augmented Solow model approach. The results showed that the growth rate of GDP per capita was negatively related to the rate of population growth and positively related to the level of investment in physical capital and human capital. They also found that FDI had a positive effect on GDP growth per capita and this effect was intensified by urban human capital ownership.

Previous research to see the effect of money supply (ms) and SBI interest rates with the title Impact of Monetary Policy on Economic Growth in Indonesia in 1999-2014 and the results of the study are all variables, namely inflation, interest rates, investment and total circulating money has a significant effect on Indonesia's economic growth in the period $1999-2014$ [20].

\section{CONCLUTION}

Based on the results of the research and discussion described previously, a number of conclusions can be drawn as follows:

1. Investment has a positive influence on economic growth in Indonesia and is statistically significant at a $90 \%$ confidence level and in accordance with theoretical conclusions. In theory, if investment increases, economic growth will increase. Because investment is the formation of capital that can improve the economy. The higher the value of investments being managed, the economic conditions will increase.

2. SBI interest rates have a negative influence on economic growth in Indonesia, 
and are statistically significant at a $90 \%$ confidence level and in accordance with the theory. Interest rates are a function of investment. Low interest rates will make investment increase and will ultimately affect economic growth that will increase.

3. The money supply has a negative effect on growth. The influence is statistically significant at the $90 \%$ confidence level but it is not in accordance with the theory. An increase in the money supply will cause an increase in investment and will have an impact on economic growth. However, an increase in the money supply can also reduce investment because an increase in the money supply will cause an increase in inflation so that investors will be less interested in investing their capital. The decline in investment will have an impact on the decline in economic growth.

4. The inflation rate (inf) and the dollar exchange rate against the Rupiah (rer) have no effect on economic growth

5. All independent variables simultaneously affect economic growth in Indonesia for the period 2010-2017.

\section{ACKNOWLEDGMENT}

A. Drs. Andreas Chang,M.B.A, as a rector of School Creative Technology Bina Nusatara Bandung, who has encouraged and motivated us to write this paper.

B. Dr. Rudy Aryanto, as a head of Creativepreneurship Department of School Creative Technology Bina Nusatara Bandung, for guidance and direction us to accomplish this paper.

\section{REFERENCES}

1. Bank Indonesia, "Laporan Bank Indonesia, Tahun 2012-2016."

2. M. Nanga, Makroekonomi : teori, masalah, dan kebijakan. Jakarta: PT. Grafindo Perkasa, 2005.

3. A. Murni, Ekonomika Makro. Jakarta: PT. Refika Aditama, 2006.

4. N. G. Mankiw, Teori Makroekonomi, 5th ed. Jakarta: erlangga, 2003.

5. E. Levy-Yeyati and F. Sturzenegger, "To Float or to Fix: Evidence on the Impact of Exchange Rate Regimes on Growth," Am. Econ. Rev., vol. 93, no. 4, 1173-1199, 2003.

6. A. . Gosh, A.-M. Gulde, and H. . Wolf, "Exchange Rate Regimes Choices and Consequences," J. Econ., 2004.

7. Gilarso, Pengantar Ilmu Ekonomi Makro. Yogyakarta: Kanisius, 2004.

8. E. Tandelilin, Portofolio dan Investasi: Teori dan Aplikasi. Yogyakarta: BPFE, UGM, 2010.

9. A. Septian, "Pengaruh Inflasi dan Tingkat Pengangguran Terhadap Pertumbuhan Ekonomi Di Indonesia.," I-Economi, 2016.

10. S. L. Dewi, "Pengaruh PAD, PMA, dan Inflasi terhadap Pertumbuhan Ekonomi di Provinsi Bali," E-Jurnal EP Unud, vol. 2 (11) : 5, 2012.

11. Sarwedi, "Investasi Asng, Langsung di Indonesia dan Faktor yang Mempengaruhinya," J. Akunt. Keuang., vol. 4, 2002.

12. A. W. Lestari, "PENGARUH JUMLAH USAHA, NILAI INVESTASI, DAN UPAH MINIMUM TERHADAP PERMINTAAN TENAGA KERJA PADA INDUSTRI KECIL DAN MENENGAH DI KABUPATEN SEMARANG," Econ. Dev. Anal. J., vol. 4, 2015.

13. E. Alfaro, "FDI and Economic Growth: the role of local financial markets," J. Int. Econ., vol. 64, pp. 89-112, 2004.

14. W. Athukorala, "The Impact of Foreign Direct Investment for Economic Growth: A Case Study in Sri Lanka," vol. 92, 2003.

15. Y. Su and Z. Liu, "the impact of FDI and human capital on economic growth in China," China Econ. Rev., vol. 37, 2016.

16. P. A. Samuelson and W. D. Nordhaus, Ilmu Ekonomi Makro. Jakarta: PT. Media Edukasi, 2004.

17. [17] R. Dornbush, S. Foshcer, and R. Startz, Macroeconomics, 11th ed. 2011.

18. M. McKenzie and R. Faff, "Macroeconomic news announcements and the role of expectations: evidence for US bond, stock and foreign exchange markets," Multinatl. Financ. Manag., vol. 14, no. 3, pp 217-232, 2004

19. G. P. Kouretas, "Long Run Purchasing Power Parity and Structural Change," Int. Econ., 2001.

20. Susandiana, "Dampak kebijakan moneter terhadap pertumbuhan ekonomi di Indonesia,” 2016.

\section{AUTHORS PROFILE}

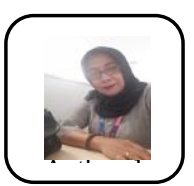

Nur Azmi Karim, Completed a Bachelor's degree in Economics and Business from Hasanuddin University in Makassar (1995), completed a master's degree in Economics and Business in Hasanuddin University in Makassar (2010), and is currently completing his Doctoral in Economics at the Faculty of Economics and Business, bina nusantara university in Bandung. My publication for the past three years is The Relationship Between Financial Intermediation and Financial Inclusion in West Java Province Indonesia 2010 - 2015 (2017), Comparative Study of Inequality in Economic Development Between Regencies / Cities in West Java Province (Klassen's Typology Analysis Approach and Wiliamson's Index Analysis) (2018), and Influence of Investment and Wage Level On Labour Migration (2019).

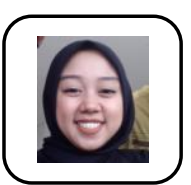

Chyntia Ika Ratnapuri Completed a Bachelor's degree in Managemen from Katolik Parahyangan University (2014), completed a master's degree in Institut Tegnology Bandung (2010). My my previous research was Proposed Strategy Formulation and Implementation for Puri Luluran Wanoja (2014), Comparing The Bussiness Process in Creative Industry at Bandung (2017), The Effect of Entrepreneurship Education to the Number of Entrepreneurs: Cross-sectional Study from Indonesia (2019). 